\title{
VAISTINIŲ AUGALŲ PAIEŠKA CUKRINIO DIABETO PREVENCIJAI
}

\author{
Aušra Adomėnienè ${ }^{1,2}$, Rita Kazernavičiūtè ${ }^{2}$, Petras Rimantas Venskutonis ${ }^{2}$ \\ ${ }^{1}$ Kauno kolegijos Medicinos fakultetas, ${ }^{2}$ Kauno technologijos universiteto \\ Cheminès technologijos fakultetas
}

Raktažodžiai: $\alpha$-gliukozidazès inhibitoriai, hiperglikemija, substratas.

\begin{abstract}
Santrauka
Viena iš pagrindinių priežasčių, susijusių su metabolinèmis ligomis - padidèjęs gliukozès kiekis kraujyje. Sveikatai pavojingiausia lètinè hiperglikemija, kuri pradiniais raidos etapais būna besimptomè, tačiau per kelerius metus gali sukelti daugelio organų ir jų sistemų ilgalakius pažeidimus. Šiame tyrime atkreiptinas dėmesys ị vaistinių augalų, galinčių slopinti $\alpha$-gliukozidazès fermentą, paiešką. Tyrimams pasirinktos dvi Dioskorejos (Dioscorea spp.) rūšys: kaukazinè dioskorejja (Dioscorea caucasica Lipsky) ir niponinè dioskorèja (Dioscorea nipponica Makino), auginamos Vytauto Didžiojo universiteto Kauno botanikos sodo vaistinių augalų kolekcijoje. Tikslas - nustatyti in vitro Dioskorejos lapų ir šaknų ekstraktų slopinimo savybes $\alpha$-gliukozidazès fermentui bei ivertinti antioksidacines savybes. Tyrimo metu nustatyta, kad kaukazinių ir niponinių dioskorejjų lapų ekstraktai $(200 \mu \mathrm{g} / \mathrm{ml})>50 \%$ slopino $\alpha$-gliukozidazès fermentą, šaknų ekstaktai $(200 \mu \mathrm{g} / \mathrm{ml})$ pastaraji fermentą slopino silpnai: 20,28 \% kaukazinès ir 17,87\% niponinès dioskorejos ekstraktai. Ivertintos dioskorejjos lapų ekstraktų antioksidacinès savybès, taikant kelis matavimo metodus: DPPH ir $\mathrm{ABTS}^{-+}$modelinèse sistemose. Pastebèta, kad tirti augaliniai ekstraktai yra gana stiprūs antioksidantai ir pakankamai efektyviai slopina hidralazių šeimos fermentą $\alpha$-gliukozidazę, todèl tokie ekstraktai galètų būti vartojami hiperglikemijos prevencijai, o taip pat ir kaip natūralūs antioksidantai.
\end{abstract}

\section{İvadas}

Lietuvoje, kaip ir daugelyje Europos šalių, dideja ịvairaus amžiaus grupių gyventojų sergamumas cukriniu diabetu (CD). Pagal Tarptautinès diabeto federacijos (TDF) duomenis, 2011 metais pasaulyje cukriniu diabetu sirgo apie 366 mln. žmonių [3], o 2013 metais jau apie 382 milijonus [4]. Numatoma, kad 2030 metais cukriniu diabetu sirgs apie
552 mln. žmonių [13]. Ligos atsiradimui didelès įtakos turi padidejusi gliukozės koncentracija kraujyje (angl. hyperglycemia), kuri pasaulyje pripažinta kaip vienas iš reikšmingiausių cukrinio diabeto rizikos veiksnių. Gliukozès apykaitos sutrikimas žmogaus organizme dažniausiai siejamas su angliavandenių ịsisavinimo žarnyne sutrikimu, kuriam didelę ìtaką turi padidèjusi fermento $\alpha$-gliukozidazès ekspresija. Šis fermentas atlieka lemiamą vaidmenį biocheminiuose procesuose, skaidydamas polisacharidus i monosacharidus, kurie vèliau absorbuojami ị kraują. Siekiant slopinti cukrinio diabeto vystymąsi, pagrindinis dèmesys skiriamas $\alpha$-gliukozidazès inhibitoriams (AGI). Pastarieji, slopindami $\alpha$-gliukozidazès fermentą proksimalinèje plonojo žarnyno epitelinio šepetinio sluoksnio dalyje, lètina angliavandenių ịsisavinimą ir sumažina gliukozès kiekio koncentraciją kraujyje po valgio [5]. Gerai žinoma, kad AGI, kaip ir kiti vaistai, gali sukelti šalutinị poveikị (dujų susikaupimą žarnyne, diskomfortą pilve, viduriavimą) [5], todèl greta efektyvių sintetinių vaistų, mažinančių gliukozės kiekị kraujyje, pastaruoju metu ieškoma augalinès kilmès $\alpha$-gliukozidazès inhibitorių. Kasmet publikuojama vis daugiau straipsnių apie Europos šalyse mažiau žinomų augalų rūšių taikymą medicinoje. Šis tyrimas skirtas dviem Dioskorejinių (Dioscoreaceae) šeimos genties rūšims - kaukazinei dioskorèjai (Dioscorea caucasica Lipsky) ir niponinei dioskorejai (Dioscorea nipponica Makino sin. Dioscorea polystachya Tures), kurios auginamos Vytauto Didžiojo universiteto Kauno botanikos sodo vaistinių augalų kolekcijoje.

Dioskorejos (Dioscorea spp.) - daugiametès, dvinamès, neryškiais žiedais iki keturių metrų aukščio užaugančios laipiojančios lianos, plačiai paplitusios tropinèse ir subtropinèse klimato juostose, tačiau nemažai dioskorejjos rūšių aptinkama ir vidutinio klimato juostoje. Lietuvoje savaime dioskorejos neauga. Sistemiškai Dioscorea gentis priskiriama Magnoliophyta - Magnolijūnų (gaubtasèklių) skyriui, $\mathrm{Ma}$ gnoliopsida - Magdolijainių (dviskilčių) klasei, Dioscoreales - dioskorèliečių eilei, Dioscoreaceae - dioskorèjinių šeimai [6]. Šiai šeimai priskiriama daug augalų rūšių, kurie sintetina skirtingus biologiškai veiklius junginius ir yra taikomi 
medicinos, maisto ir kitu produktų gamybos tikslais. Verta paminèti, kad kaukazinè dioskorèja (D. caucasica Lipsky) laikoma tretinio laikotarpio endeminiu reliktu. Šios rūšies buveine Šiaurès Kaukaze užima labai mažus plotus, išilgai besidriekiančius Juodosios jūros pakrante nuo Mzymta upès iki upès Kodor [7]. Žinoma, kad šios dvi rūšys ir jų augalu dalys pritaikomos medicinos ir sveikatos stiprinimo praktikoje. Išskirtas steroidinis sapogeninas - diosgeninas, naudojamas farmacijos pramoneje kaip pirmtakas (prekursorius) steroidinių vaistų sintezeje [11]. Šiose rūšyse vyraujantys saponinai: dioscinas (D.nipponica, D. caucasica), gracilinas, protogracilinas, protodioscinas; fenolinès rūgštys: piscido rūgštis (D.nipponica) fenoliniai junginiai, amino rūgštys $[8,11,12]$ padeda stiprinti imuninę sistemą, atitolindamos lètinių neinfekcinių ligų vystymąsi.

Darbo tikslas - ištirti kaukazinès ir niponinès dioskorejjos lapų ir šaknų ekstraktų gebą slopinti $\alpha$-gliukozidazès fermentą bei antioksidacines savybes.

\section{Tyrimo objektas ir metodai}

Tyrimams pasirinkta kaukazinè ir niponinè dioskorèja. Tirti dioskorejų lapų èminiai surinkti žydejjimo pradžioje, šaknys iškastos vegetacijos laikotarpiu. Išdžiovinti susmulkinti (IKA A11 Basic, Vokietija) mèginiai ekstrahuojami maceruojant $70 \%(\mathrm{v} / \mathrm{v})$ etanolyje kambario temperatūroje, santykiu 1:10. Gautas tirpalas filtruojamas, tirpiklis (etanolis) išgarinamas rotaciniame garintuve $40{ }^{\circ} \mathrm{C}$ temperatūroje, o vanduo pašalinamas liofilizuojant. Gautas liofilizuotas sausas ekstraktas tyrimams naudotas kaip natūralus $\alpha$-gliukozidazès fermento inhibitorius. Alfa gliukozidazès veikimo mechanizmas ir inhibitoriaus ittaka fermentui parodyta 1 paveiksle.

Dioskorejos ekstraktų slopinamosios savybès $\alpha$-gliukozidazès fermentui atliktos chromogeniniu analizès metodu, naudojant p-nitrophenyl- $\alpha$-D-gliukopiranozidą ( $p \mathrm{NPG}$ ) kaip substratą. Spektofotometriniai matavimai (Genesys 8, Thermo Spectronic, Rochester, $\mathrm{NY}$ ) atlikti 0,1 M kalio fosfato buferiniame tirpale (pH 6,8 \pm 0.01$) 1 \mathrm{~cm}$ storio vienkartinèje kiuveteje, esant $10 \mu \mathrm{l}$ augalinio ekstrakto, $65 \mu \mathrm{L} p \mathrm{NPG}, 5 \mu \mathrm{l} \alpha$-gliukozidazès fermento. Tiriamųjų tirpalų reakcijos pradètos ịpilant $\alpha$-gliukozidazès fermento tirpalą. Produkto susidarymas $(p N P G+\alpha$-gliukozidaze $\rightarrow \alpha$-Dgliukozè + pNPG) buvo stebimas po $30 \mathrm{~min}$, esant $405 \mathrm{~nm}$ bangų ilgiui. Fermentinè reak- cija buvo vykdoma $37 \pm 2{ }^{\circ} \mathrm{C}$ temperatūroje. Kontrolinis tirpalas buvo identiškas tiriamajam, tik vietoje inhibitoriaus tirpalo naudotas $0,1 \mathrm{M}$ kalio fosfato buferinis tirpalas $(\mathrm{pH}$ $6.8 \pm 0.01$ ). Fermento $\alpha$-gliukozidazès aktyvumo sumažejimas procentais apskaičiuojamas pagal formulę: aktyvumo sumažèjimas $(\%)=\left[\mathrm{A}_{405}\right.$ kontr. $-\mathrm{A}_{405}$ mèg./ $\left.\mathrm{A}_{405} \mathrm{kontr}.\right] \mathrm{x} 100$, kurioje:

Akontr-- kontrolinio tirpalo šviesos sugertis;

Amèg. - tiriamojo tirpalo šviesos sugertis.

Dioskorèjos ekstraktu geba sujungti laisvuosius radikalus nustatyta 2,2-difenil-pikrilhidrazilo hidrato (DPPH') metodu, aprašyta W. Brand-Williams ir kt [2]. DPPH radikalo sujungimo geba nustatyta sumaišius $300 \mu \mathrm{l} \mathrm{DPPH}^{\cdot}(6,5 \mathrm{x}$ $\left.10^{-5} \mathrm{~mol}^{-1}\right)$ ir $7,5 \mu$ tiriamujų mèginių tirpalus $(1 \mathrm{mg} / \mathrm{ml})$. Reakcijos mišinys laikomas tamsoje 30 minučių. Mèginių absorbcijos pokyčiai išmatuoti spektrofotometru (FLUOstar Omega (BMG LABTECH, Vokietija), esant $515 \mathrm{~nm}$ bangu ilgiui. Vandens ir metanolinio DPPH tirpalo mišinys buvo naudojamas kaip palyginamasis tirpalas. DPPH' sujungimo geba (\%), apskaičiuota kaip ir $\alpha$-gliukozidazès fermento slopinimui.

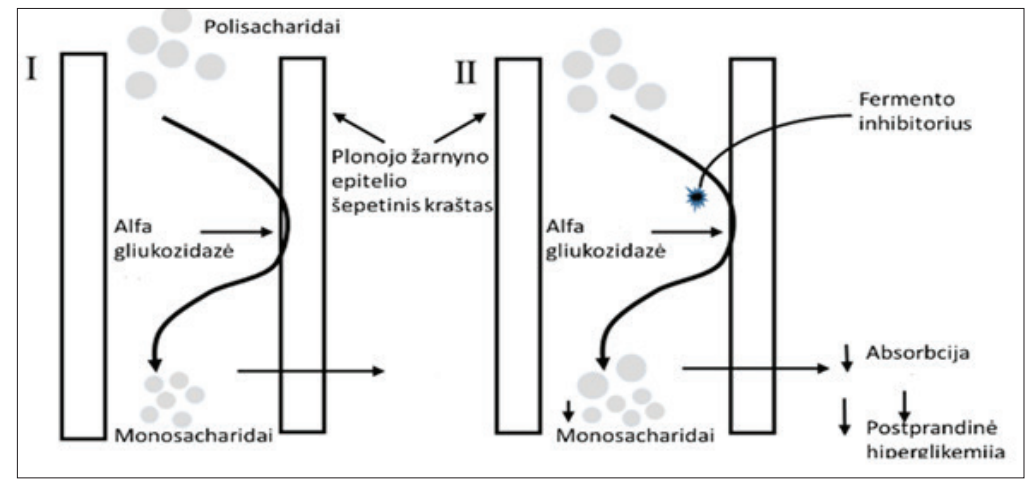

1 pav. Alfa gliukozidazès veikimo mechanizmas. Adaptuotas iš G. Aruangarinathan ir kt. [1]:

I - alfa gliukozidazés fermentas skaido polisacharidsus ir (ar) oligosacharidus i monosacharidus; II - padidejęs alfa gliukozidazés aktyvumas nevisiškai suskaido polisacharidus, gali sukelti metabolinius sutrikimus. AGI slopina fermento aktyvuma, mažindami gliukozés kiekio koncentracija kraujyje po valgio

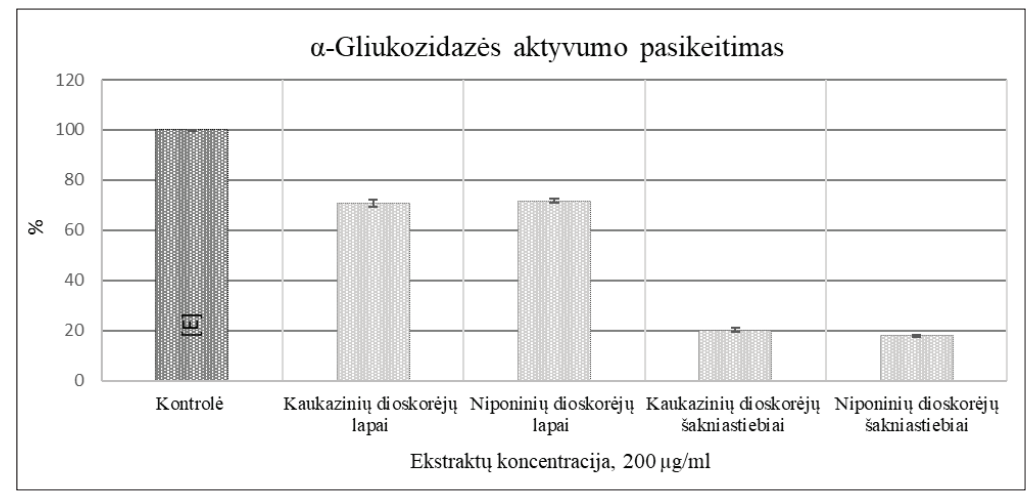

2 pav. Dioskorejų ekstraktų ịtaka $\alpha$-gliukozidazès aktyvumui 
2,2'-azino-bis-(3-etilbenztiazolin-6-sulfono rūgšties $\left(\mathrm{ABTS}^{\circ+}\right.$ ) radikalo katijono sujungimo gebai nustatyti [11] reakcijos mišinys $6,7 \mathrm{mM} \mathrm{ABTS} / 2,45 \mathrm{mM} \mathrm{K}_{2} \mathrm{~S}_{2} \mathrm{O}_{8}$ santykiu 1:2 paliekamas 16 valandu tamsoje, kad susidarytų $\mathrm{ABTS}^{\cdot+}$. Prieš atliekant antioksidacinio aktyvumo tyrimą (AA), ABTS $^{++}$tirpalas skiedžiamas fosfatiniu drusku (PBS) buferiu (pH 7,4), kol pasiekiama $0.8 \pm 0.03$ absorbcija, esant $734 \mathrm{~nm}$ bangos ilgiui.

$\mathrm{ABTS}^{++}$radikalo sujungimo geba nustatyta sumaišius $300 \mu \mathrm{ABTS}^{++}$ir $3 \mu \mathrm{l}$ tiriamujjų mėginių tirpalo. Mèginių absorbcijos pokyčiai išmatuoti spektrofotometru FLUOstar Omega, esant $734 \mathrm{~nm}$ bangos ilgiui. Dioskorejos lapų ekstrakto antiradikalinis aktyvumas in vitro išreikštas trolokso ekvivalentu (mgTE/g).

Statistinių duomenų įvertinimas. Statistinè analizė atlikta naudojant programinị paketą MS Office Excel 2016 (Microsoft Corporation, JAV). Statistinès duomenų analizės metu skaičiuoti duomenų vidurkiai, standartiniai nuokrypiai. Rezultatų patikimumas įvertintas Student's testu.

\section{Tyrimo rezultatai}

Tiriant in vitro dioskorejos lapų sausų ekstraktų slopinanti poveikị $\alpha$-gliukozidazès fermentui, nustatyta, kad niponinių ir kaukazinių dioskorejjų lapų ekstraktai $>50 \%$ šị fermentą slopina (2 pav.).

Abiejų dioskorèjos rūšių bendri $\alpha$-gliukozidazès aktyvumo rezultatai reikšmingai nesiskyrè: $200 \mu \mathrm{g} / \mathrm{mL}$ kaukazinés dioskorejos lapų ekstraktas fermentą slopino 70,39\% (95\% PI: 68,92 - 71,86), niponinės dioskorejjos lapų ekstraktas fermentą slopino 71,70 \% (95\% PI: 70,84 - 72,54). Priešingai nei dioskorejos lapų ekstraktai, šaknų ekstraktai (200 $\mu \mathrm{g} / \mathrm{ml}) \alpha$-gliukozidazès fermentą slopino silpnai: kaukazinès dioskorèjos - 20,28 \% ( 95\% PI: 19,46-21,64); niponinès dioskorejos - 17,87 \% ( 95\% PI: 17,6-18,14) . Nustatyti reikšmingi skirtumai tarp lapų ir šaknų ekstraktų. Padidinus dioskorejų šaknų ekstraktų koncentraciją nuo $0,5 \mathrm{mg} / \mathrm{ml}$ iki $1,0 \mathrm{mg} / \mathrm{ml}, \alpha$-gliukozidazès aktyvumas sumažèjo (jis buvo atitinkamai $40,6 \%$ ir 47,85\%, kaukazinès dioskorejos; $39,25 \%$ ir 46,1 \% niponinès dioskorejjos) tačiau nepasiekè 50 procentų slopinimo. Nustatyta, kad niponinių ir kaukazinių dioskorejų lapų ekstraktai veiksmingai neutralizuoja laisvuosius radikalus: D. nipponica $415 \pm 9 \mathrm{mgTE} / \mathrm{g} \mathrm{DPPH}$ metodu ir $659 \pm 4 \mathrm{mgTE} / \mathrm{g} \mathrm{ABTS}^{-+}$metodu: $D$. caucasica $279 \pm 4 \mathrm{mgTE} / \mathrm{g}$ DPPH metodu ir $880 \pm 10 \mathrm{mgTE} / \mathrm{g} \mathrm{ABTS}^{++}$ metodu. Taikant kelis matavimo metodus, rūšių antioksidacinès savybės reikšmingai skyrèsi: DPPH metodu niponinès dioskorejos lapų ekstraktas laisvuosius radikalus neutralizavo stipriau, nei kaukazinès (atitinkamai $415 \pm 9 \mathrm{mgTE} / \mathrm{g}$ ir $279 \pm 4 \mathrm{mgTE} / \mathrm{g}$, vidutinis skirtumas $136 \mathrm{mgTE} / \mathrm{g}$, $\mathrm{p}<$ 0.0001 ); priešingai, $\mathrm{ABTS}^{++}$metodu niponinių dioskorèjų lapų ekstraktai laisvuosius radikalus neutralizavo silpniau, nei kaukazinès (atitinkamai $659 \pm 4 \mathrm{mgTE} / \mathrm{g}$ ekstrakto ir 880 $\pm 10 \mathrm{mgTE} / \mathrm{g}$ ekstrakto), vidutinis skirtumas $222 \mathrm{mgTE} / \mathrm{g}$, $\mathrm{p}<0.0001$.

\section{Išvados}

1. Tiriant dioskorejų lapų ekstraktų antioksidacines savybes DPPH ir $\mathrm{ABTS}^{\cdot+}$ metodais, nustatyta, kad kaukazinès ir niponinès dioskorèjos lapų ekstraktai yra gana stiprūs antioksidantai.

2. Tiriant dioskorejjų ekstraktų slopinamąsias savybes $\alpha$-gliukozidazės fermentui, nustatyta, kad lapų ekstraktai efektyviai slopina hidralazių šeimos fermentą $\alpha$-gliukozidazę, todèl tokie ekstraktai galètų būti vartojami hiperglikemijos prevencijai ir kaip natūralūs antioksidantai.

3. Šio tyrimo rezultatai skatina tolimesnius tyrimus, siekiant išskirti konkrečius, $\alpha$-gliukozidazès fermentą slopinančius ir radikalus sujungiančius fitocheminius junginius.

\section{Literatūra}

1. Aruangarinathan G, McKay GA, Fisher M. Drug for diabetes: part 4 diabetes. Br J Cardiol 2011;18:78 - 81 .

2. Brand-Williams W, Cuvelier ME, Berset C. Use of a free radical method to evaluate antioxidant activity. LWT Food Sci Technol 1995; 28 (1):25-30.

https://doi.org/10.1016/S0023-6438(95)80008-5

3. IDF diabetes atlas. International Diabetes Federation, Brussels, Belgium 2011.

4. IDF diabetes atlas. International Diabetes Federation, Brussels, Belgium 2013.

5. Inzucchi SE. 2 tipo cukrinio diabeto gydymas peroraliniais glikemiją mažinančiais vaistais. Diabeto panorama, 2005;(6):8 -17. https://www.emedicina.lt/site/files/diabeto_panorama/2005_01/2_tipo.pdf

6. ITIS Standard Report. Taxonomic Information System. http:// www.itis.gov

7. Krylova IL. Dioscorea caucasica Lipsky - areal, morphology, biology and ecologic-cenotical characteristic. Rast Resourses 1996;1-13.

8. Ou-Yang SH, Jiang T, Zhu L, Yi T. Dioscorea nipponica Makino: a systematic review on its ethnobotany, phytochemical and pharmacological profiles. Chem Cent J 2018;12(1):57.

https://doi.org/10.1186/s13065-018-0423-4

9. Paškevičius A, Ivanovienė L, Gailys R, Sadauskienė I. ir kt. Dažniausiai vartojamų biomedicinos terminų ir sąvokų aiškinamasis žinynas. LSMU leidybos namai, 2014:494.

10. Re R, Pellegrini N, Proteggente A, Pannala A, Yang M, Rice-Evans C. Antioxidant activity applying an improved ABTS radical cation decolorization assay. Free Rad Biol Med 1999;26:1231-1237.

https://doi.org/10.1016/S0891-5849(98)00315-3 
11. Tang W, Eisenbrand G. Chinese drugs of plant origin: chemistry, pharmacology, and use in traditional and modern medicine. Springer-Verlag 1992:459 -472. https://doi.org/10.1007/978-3-642-73739-8_59

12. Vasil'eva IS, Paseshnichenko VA, Guseva AR. Steroid saponins from the rhizomes of Dioscorea caucasica Lipsky. Prikl Biokhim Mikrobiol 1984;20(3):404-6. PMID: 6235520. Russian.

13. Whiting DR, Guariguata L, Weil C, Shaw J. IDF diabetes atlas: estimates of the prevalence of diabetes for 2011 and 2030. Diabetes Res Clin Pract 2011; 94(3):311-321.

https://doi.org/10.1016/j.diabres.2011.10.029

A SEARCH FOR MEDICINAL PLANTS SUITABLE FOR THE PREVENTION OF DIABETES MELLITUS A. Adomėnienė, R. Kazernavičiūtė, P.R. Venskutonis

Key words: $\alpha$-glucosidase inhibitors, hyperglycemia, substrat. Summary

An elevated blood glucose level is one of the main causes of metabolic diseases. Chronic hyperglycemia, which is asymptomatic in the early stages of development but is likely to cause longterm damage to many organs and their systems over a few years, is the most dangerous to health. This study focused on the search for medicinal plants that can inhibit the $\alpha$-glucosidase enzyme.
Two species of Dioscorea (Dioscorea spp.) were selected for the study - Dioscorea caucasica Lipsky and Dioscorea nipponica Makino grown in the collection of medicinal plants in the Botanical Garden of Vytautas Magnus University in Kaunas. The aim of the study was to determine the in vitro inhibitory properties of Dioscorea leaf and root extracts on the enzyme $\alpha$-glucosidase and to evaluate their antioxidant properties. The study showed that leaf extracts of Dioscorea caucasica Lipsky and Dioscorea nipponica Makino $(200 \mu \mathrm{g} / \mathrm{ml})$ inhibited the $\alpha$-glucosidase enzyme by $>50 \%$. Meanwhile, the inhibitory effect of root extracts $(200 \mu \mathrm{g} /$ $\mathrm{ml}$ ) on this enzyme was weak: root extracts of Dioscorea caucasica Lipsky inhibited this enzyme by $20.28 \%$, and root extracts of Dioscorea nipponica Makino - by $17.87 \%$. The antioxidant properties of Dioscorea leaf extracts were evaluated using DPPH and $\mathrm{ABTS}^{\cdot+}$ assays. The results of the evaluation showed that the studied plant extracts were quite strong antioxidants and sufficiently effectively inhibited the enzyme $\alpha$-glucosidase of the hydrolase family, and thus such extracts could be used for the prevention of hyperglycemia and as natural antioxidants.

Correspondence to: ausra.adomeniene@go.kauko.lt

Gauta 2020-10-18 